KappT \& Jacobs LJ

\title{
'N GEÏNTEGREERDE GESINSTERAPEUTIESE WERKWYSE MET HERSAAMGESTELDE GESINNE
}

T Kapp BEd, Opvoedkundige Voorligting en Berading; LJ Jacobs BA(MW), Direkteur van die Sentrum vir Kinder- en Volwasseneleiding aan die Universiteit van Pretoria

\begin{abstract}
By using an integrative family therapy model, this article addresses the multiple problems a stepfamily may encounter. The stepfamily is a rapidly growing family structure in modern society. The stepfamily's unique problems, for instance, life-cycle discrepancies and loyalty conflicts, begin when they start functioning together as a family. The problematic foundation of a stepfamily and its unique composition require a specific therapeutic method that will take the complexities of those families into account. The researchers used the integrative family therapy model of David C. Olsen. This model is constructed out of six accredited methods in the field of family therapy: the problem solving, structural, interactional, cognitive, multigenerational and object-relation methods.
\end{abstract}

\section{INLEIDING}

Die hedendaagse lewe word gekenmerk deur snelle verandering op tegnologiese, kulturele, sosiale en politieke gebied. Een van die opvallendste veranderinge en tendense van ons tyd is die disintegrasie van die kerngesin. Die hersaamgestelde gesin is nie 'n nuwe konsep nie. Van die vroegste tye af was daar as gevolg van die dood van 'n huweliksmaat sprake van die teenwoordigheid van 'n stiefouer. Wat wel nuut en anders is, is die tempo waarteen die hersaamgestelde gesin die tradisionele gesin vervang, asook die redes vir die totstandkoming van die hersaamgestelde gesin en die gepaardgaande problematiek. Die hersaamgestelde gesin se problematiese situasies word deur Booth en Dunn (1994:7) beskryf as 'n mynveld van verdeelde lojaliteite, emosionele lokvalle en bestuurskonflikte, wat hierdie gesinsvorm broos laat.

Die belangstelling in gesinsterapie as ' $\mathrm{n}$ behandelingsmetode het derhalwe gedurende die afgelope twee dekades geweldig toegeneem. Lebow (1987:1) het reeds in die tagtigerjare bevind dat daar 'n opmerklike ontwikkeling in die veld van gesinsterapie en 'n geweldige toename in belangstelling in die integrasie van gesinsterapeutiese metodes is. 'n Legio gesinsterapeutiese teorieë behandel verskeie aspekte van die gesin. In dié verband pas terapeute gewoonlik die werkwyse waarmee hulle gemaklik voel toe die vraag ontstaan egter: Sal die gekose werkwyse die spesifieke gesin se problematiek aanspreek - veral as die veelvuldige problematiek van hersaamgestelde gesinne in aanmerking geneem word?

In hierdie artikel sal 'n geïntegreerde gesinsterapeutiese model (ontwikkel deur David C. Olsen) voorgehou word. Hierdie model is saamgestel uit verskeie erkende gesinsterapeutiese metodes wat volgens die skrywers suksesvol op die hersaamgestelde gesin toegepas kan word. Deur middel van 'n literatuurstudie sal die probleemareas van die hersaamgestelde gesin en die ses metodes waaruit die geïntegreerde gesinsterapeutiese model saamgestel is, eerstens kortliks weergegee word. Die model sal daarna bekendgestel word, gevolg deur die bevindings van die skrywers na aanleiding van die toepassing van die model. 


\section{PROBLEMATIEK VAN DIE HERSAAMGESTELDE GESIN}

Hoë egskeiding- en hertrousyfers het tot gevolg dat die hersaamgestelde gesin 'n vinnig groeiende vorm van gesinslewe in die huidige samelewing word. Daar blyk veral 'n dramatiese groei in die aantal egskeidings in Suid-Afrika te wees. Volgens die nuutste beskikbare statistiek van die Sentrale Statistieksdiens van Suid-Afrika (verslag P0307) was daar 34231 egskeidings in 1997, wat in 1998 tot 35792 toegeneem het. Die aangepaste egskeidingsyfer vir die hele Suid-Afrika het van 643 per 100000 in 1997 toegeneem tot 662 per 100000 in 1998 . Die toename in die aantal kinders wat in 1997 by egskeidings betrokke was teenoor die aantal in 1998 (onderskeidelik 43476 en 45 123), is opvallend.

Die media, tydskrifte en boeke het gesorg dat woorde soos egskeiding en stiefgesinne alledaags geword het, juis as gevolg van die toenemende aantal huwelike wat misluk. Dit wil voorkom asof die samelewing in die breë egter nog onkundig is oor die unieke aard en samestelling van die hersaamgestelde gesin. Hersaamgestelde gesinne blyk ook 'n groter risiko te loop om 'n tweede keer te misluk. Parkinson (1987:133) het reeds in die tagtigerjare bevind dat die risiko vir die mislukking van 'n gesin met 'n stiefvader besonder hoog is: Een uit elke vyf kinders wat by 'n stiefvader gewoon het, was teen die ouderdom van elf jaar nie meer in daardie situasie nie. (Dit word genoem om aan die leser te toon dat, volgens statistieke, die risiko groter is dat 'n tweede huwelik misluk, en nie dat dit die stiefvader se skuld is dat die tweede huwelik misluk nie.)

Die lede van die hersaamgestelde gesin begin (anders as by die kerngesin) hul lewens met verswarende omstandighede. Die gesinslede bestaan uit 'n netwerk van persone en verhoudinge wat uit die verlies (egskeiding of dood) van 'n huweliksmaat of 'n ouer, of uit 'n hertroue ontstaan het. Die hersaamgestelde gesin het dus sowel bande met die verlede as die hede en word op 'n komplekse en potensieel problematiese fondament gebou.

\section{Verandering en verlies}

Die ontstaan van 'n hersaamgestelde gesin hou vele verliese op verskillende vlakke vir ál die betrokkenes in. Verreikende veranderinge vind ook plaas, byvoorbeeld 'n kind wat skielik 'n kamer moet deel. Verliese vir volwassenes sluit aspekte soos minder tyd en gebrek aan persoonlike vryheid in (Visher \& Visher, 1988:91-120).

\section{Onrealistiese mites}

Daar is verskeie mites wat die proses van bevredigende integrasie in die hersaamgestelde gesin bemoeilik, onder meer:

- Hersaamgestelde gesinne is dieselfde as kerngesinne.

- Die aanpassing by 'n hersaamgestelde gesin is van korte duur.

- Wedersydse liefde sal onmiddellik ontstaan.

Hoe meer die egpaar se rooskleurige verwagtinge en die ontnugterende realiteit van mekaar verskil, hoe groter die teleurstelling (Du Plessis, 1994:65-68).

\section{Groepvorming binne die hersaamgestelde gesin}

Die bewustheid van eksklusiewe emosionele bande tussen lede van een biologiese gesin kan tot groepvorming lei, wat die lede van die ander gesin kan uitsluit. Veral wanneer albei ouers gesinne saambring, bestaan daar twee verskillende subgroepe wat poog om dieselfde ruimte in 'n huis te deel. Nuwe rituele en tradisies (bv. vakansietradisies) en daaglikse roetines moet 
geskep word sodat groepvorming tussen die nuwe gesinslede kan plaasvind (Visher \& Visher, 1996:77-81).

\section{Lewensiklusdiskrepansies}

'n Eerste huwelik bestaan gewoonlik uit twee volwassenes wat soortgelyke gesinservaringe gehad het en wat die ervaring van ouerskap gesamentlik begin het. 'n Hersaamgestelde gesin behels egter 'n heel verskillende prentjie. Dit kan onder andere 'n pa met 'n adolessent en 'n stiefma met geen of klein kinders insluit, wat as gevolg van die dramatiese verskille in lewensiklusfases verreikende gevolge kan hê (Carter \& McGoldrick, 1999:424-425; Visher \& Visher, 1996:81-84).

\section{Lojaliteitskonflik}

Aangesien daar soveel verskillende persone, verhoudinge (oud en nuut) en onderlinge alliansies by ' $n$ hersaamgestelde gesin betrokke is, is dit volgens Visher \& Visher (1996:84-89) verstaanbaar dat daar konflikterende lojaliteite sal wees. Heelparty ouers vrees die verlies van 'n hegte verhouding met hul eie kinders as hulle 'n sterk band met hul nuwe huweliksmaat of stiefkinders het (Carter \& McGoldrick, 1999:424; Prinsloo, 1993:45-46).

\section{Grense}

Dit is die mening van Britz-Scheepers en Du Preez (1994:242-243) dat daar talle dubbelsinnige grense in ' $n$ hersaamgestelde gesin is. Alhoewel daar duidelike grense in die huishouding moet wees, moet daar ook beweegruimte vir die kinders wees, sodat hulle tussen die huishoudings van die twee ouers kan beweeg. Faktore wat gesinsgrense beïnvloed, is die gesinskonteks, fase in die lewensiklus van die gesinslede en die hoeveelheid tyd wat tussen die huwelike verloop het (Carter \& McGoldrick, 1999:423; Prinsloo, 1993:45).

\section{Dissipline}

Dissiplinêre problematiek is ' $\mathrm{n}$ groot bron van spanning in hersaamgestelde gesinne en gemeenskaps- en familieverwagtinge vererger die problematiek. 'n Poging deur die stiefouer om die dissiplinêre rol te aanvaar, kan uiters negatiewe gevolge hê (Prinsloo, 1993:42-43).

\section{Finansies}

Geld hou op verskeie vlakke voortdurende implikasies vir hersaamgestelde gesinne in. Dit strek van praktiese implikasies, soos gereelde onderhoudsbetaling, tot implikasies op 'n emosionele vlak, byvoorbeeld 'n ouer wat as gevolg van 'n skuldgevoel 'n plek in kinders se harte wil koop (Carter \& McGoldrick, 1999:422).

\section{Gesinsrolle}

Rolle wat duidelik in 'n tradisionele gesin gedefinieer is, kan nie blindelings op 'n hersaamgestelde gesin toegepas word nie. In die afgelope twee dekades het die druk op rolle in 'n gesin toegeneem. Namate die roldefinisies minder duidelik word, kry albei ouers meer verantwoordelikhede. Hierdie druk word veral intens in 'n hersaamgestelde gesin ervaar, aangesien die stiefouerrol deur verliese en die byvoeging van rolle gekenmerk word (Kelley, 1995:39-48; Prinsloo, 1993:39-40). 


\section{Nabyheid/afstand}

In kerngesinne word die ouer-kind-verhouding gewoonlik as vanselfsprekend ervaar, terwyl dit in hersaamgestelde gesinne waargeneem, geanaliseer en gereeld krities deur die gesinslede, bure en vriende geëvalueer word. 'n Werklik liefdevolle verhouding kan met verloop van tyd tussen volwassenes en kinders ontstaan (Visher \& Visher, 1996:100-103).

\section{GEÏNTEGREERDE GESINSTERAPIE}

Die skrywers se doelstelling met die studie is om 'n pakket van gesinsterapeutiese metodes spesifiek op die hersaamgestelde gesin toe te pas, aangesien hulle van mening is dat die hersaamgestelde gesin 'n breër terapeutiese benadering verg, as gevolg van die kompleksiteit van dié gesinsamestelling en die unieke problematiek daaraan verbonde.

Tydens die bestudering van die literatuur het die skrywers op 'n geïntegreerde gesinsterapeutiese model afgekom, wat na hulle mening uiters bruikbaar met hersaamgestelde gesinne kan wees. Die geïntegreerde gesinsterapeutiese model wat die skrywers gaan gebruik, is saamgestel deur David C. Olsen, 'n pastorale gesinsterapeut en outeur van die boek Integrative family therapy. Hierdie model maak onder meer van verskeie erkende en gerespekteerde metodes uit die veld van gesinsterapie gebruik, naamlik:

i. Probleemoplossingsmetode: Die primêre doel is om die gesin se huidige probleem aan te spreek. Die fokus is op oplossings en bevoegdhede eerder as op probleme; dus op dit wat veranderbaar en moontlik is. Dit is 'n eenvoudige korttermynmetode wat op die ontwikkeling van die gesin se probleemoplossingsvaardighede fokus (Carlson, Sperry \& Lewis, 1997:59-60).

ii. Interaksionele metode: Die fokus van dié metode is op negatiewe en destruktiewe kommunikasiepatrone en die hersaamgestelde gesin se onvermoë tot effektiewe kommunikasie. Terapeute identifiseer simptome as kommunikasieboodskappe en soek herhalende gedrag wat die probleem in stand hou, sodat daardie gedrag verander kan word (Van der Westhuizen, 1997:38-39).

iii. Strukturele metode: Hierdie metode sien die sleutel tot sukses in die hersaamgestelde gesin se vermoë om aanpasbare veranderinge binne die struktuur te maak. Die primêre fokus is dus op die struktuur van die gesin en op die hede en toekoms. Elke individu in 'n gesin behoort aan 'n subsisteem binne die gesinsisteem. Daar bestaan drie subsisteme: egpaar- , ouer- en kindersubsisteme (Minuchin, 1996:2; Becvar \& Becvar, 2000:197200).

iv. Kognitiewe metode: Die persoonlike oortuigingsisteme wat probleme in die verhoudings in die gesin veroorsaak, word geïdentifiseer. Hierdie disfunksionele gedagtes en die gepaardgaande emosionele reaksies word gemonitor en die doel is om die kognitiewe distorsies (spesifiek ten opsigte van die hersaamgestelde gesin) met rasionele verklarings uit te daag (Olsen, 1993:27-29).

v. Multigeneratiewe metode: Gesinne word beskou in terme van die psigologiese dinamika wat van generasie na generasie oorgedra word. Die metode fokus op groter selfdifferensiasie van die gesin van oorsprong. Dit gaan dus oor die persoon se vermoë om hom- of haarself van sy of haar gesin van oorsprong te differensieer (Carlson et al., 1997:46; Goldenberg \& Goldenberg, 2000:170). 
vi. Objekrelasiemetode. Dit fokus op die manier waarop individue vroeë primêre verhoudinge en selfbeelde geïnternaliseer het. Hierdie geïnternaliseerde verpersoonliking formuleer 'n denkpatroon wat 'n groot invloed op die keuse van 'n huweliksmaat, verhoudingsdinamika, ens. uitoefen. Die doel van objekrelasie is nie om probleme op te los nie, maar om 'n veilige omgewing wat ontwikkeling van die gesinslede toelaat te bied (Carlson et al., 1997:71; Becvar \& Becvar, 2000:175).

\section{DIAGRAM 1 \\ DIE GEÏNTEGREERDE GESINSTERAPEUTIESE MODEL VAN DAVID C. OLSEN}

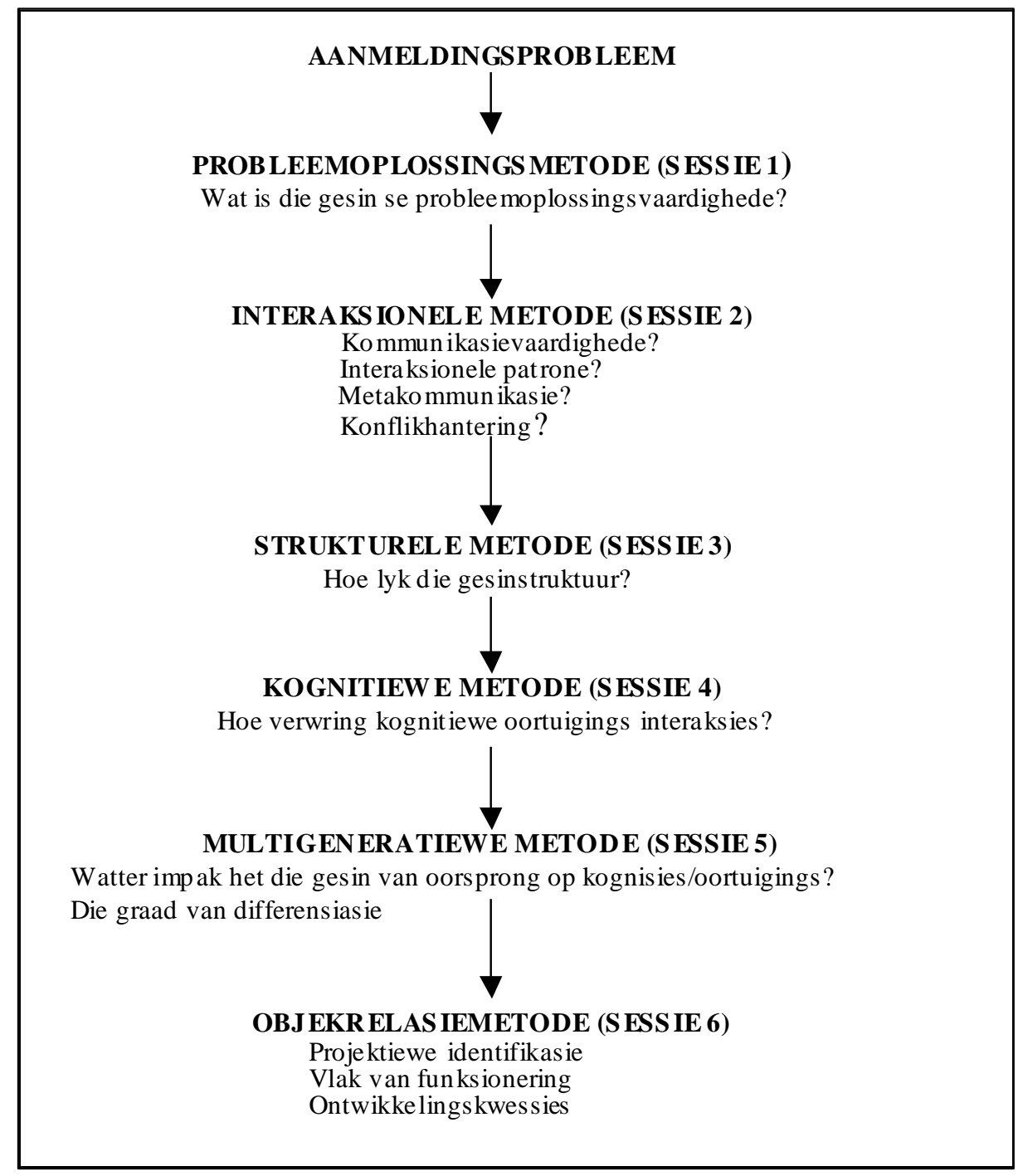


Bogenoemde ses metodes word gesamentlik as 'n geïntegreerde model gebruik om 'n gesin volgens hul spesifieke problematiek te help. Eerder as om deur die lens van 'n enkele metode na die gesin se problematiek te kyk, word 'n reeks stappe (metodes) gevolg, totdat die terapeut by die kern van die problematiek uitkom. Hierdie model bied geleentheid vir die ontvouing van die probleem sonder dat die terapeut sy of haar verwysingsraamwerk op die gesin afdwing. Dié geïntegreerde benadering tot gesinsterapie behels 'n duidelike en sistematiese terapeutiese werkswyse (Olsen, 1993:53-55). Hierdie model word vervolgens diagrammaties voorgestel sodat die leser 'n visuele indruk daarvan kan kry. (Olsen plaas die interaksionele en strukturele metodes nie volgens 'n spesifieke volgorde in sy diagram nie. Die skrywers het dit egter goed gevind om ter wille van duidelikheid vir die leser en met inagneming van die inhoud van hierdie twee metodes, eers die interaksionele metode en daarna die strukturele metode toe te pas.)

\section{NAVORSING}

\section{Metode van ondersoek}

Twee metodes van ondersoek is toegepas, naamlik:

\section{Literatuurstudie}

' $\mathrm{n}$ Literatuurstudie is uit toonaangewende bronne onderneem om meer inligting oor die volgende te bekom:

die hersaamgestelde gesin en veral die eiesoortige problematiek daaraan verbonde;

- $\quad$ 'n geïntegreerde gesinsterapeutiese model wat uit probleemoplossings-, interaksionele, strukturele, kognitiewe en objekrelasiemetodes saamgestel is.

\section{Kwalitatiewe navorsing}

Kwalitatiewe navorsing verwys na oorsake, gevolge, gesprekke en aksies. Die fokus is op die individu self en geen vergelyking met die norm vind plaas nie. Volgens Judd, Smith en Kidder (1991:299) raak veldwerkers wat kwalitatiewe navorsing doen, betrokke by die lewens van die individue wat hulle bestudeer.

Vir hierdie navorsing is die kwalitatiewe navorsingsmetode gekies, aangesien die sentrale doelstelling met navorsing gespreksvoering met unieke individue binne die hersaamgestelde gesin is.

\section{Die navorsingsontwerp}

Aangesien die navorsingsmetode kwalitatief van aard is, sentreer die navorsingsontwerp rondom die dokumentering van een volledige gevallestudie. Die selektering van die hersaamgestelde gesin sal volledig onder proefpersone bespreek word.

\section{Proefpersone}

Die samewerking van 'n hersaamgestelde gesin is deur 'n vrywillige welsynsorganisasie waarby een van die skrywers betrokke is, verkry. Die gesin bestaan uit mnr L (50 jr), mev L (37 jr), kind E ( 8 jr) en kind M ( $3 \mathrm{jr})$. Mnr L was voorheen vir 18 jaar met mev M (43 jr) getroud en hulle het drie kinders: kind I ( 24 jr), kind K (21 jr) en kind H (19 jr). Mev L was voorheen twee keer getroud. Haar eerste huwelik was met mnr F (40 jr). Sy was ook vir vyf 
jaar met mnr A (41 jr) getroud, en uit daardie huwelik is kind E gebore. Mnr en mev L het in 1996 in die huwelik getree. Met inagneming van die betrokke partye se beskikbaarheid en afhangend van die gesin se unieke situasie, was daar ses sessies.

\section{Probleemformulering}

In die lig van die hoë voorkoms van egskeiding en hertrou (wat reeds vermeld is) is dit van kardinale belang dat terapeute vertroud raak met die hersaamgestelde gesin as gesinstruktuur, asook met effektiewe behandelingstrategieë ten opsigte van hierdie gekompliseerde gesinne. Die interaksie van ontwikkelende veranderinge binne die hersaamgestelde gesin (en tussen individuele gesinslede), asook die eiesoortige en stresvolle aspekte van 'n hertroue, skep 'n komplekse web van gesinsveranderinge, wat spesiale kennis en vaardighede van 'n terapeut vereis. Terapeute kan egter maklik oorweldig voel deur die legio modelle, teorieë, metodes en werkwyses wat beskikbaar is. Gewoonlik kies die terapeut dus 'n perspektief waarin hy of sy opgelei is of waarmee hy of sy gemaklik voel.

\section{Doelstelling}

Hierdie artikel het ten doel om die multiproblematiese aard van die hersaamgestelde gesin aan te spreek deur 'n geïntegreerde gesinsterapeutiese model as werkwyse te gebruik. Die skrywers se keuse van hierdie model is gegrond op hulle redenasie dat hierdie werkwyse moontlik 'n breër en toepasliker perspektief op die hersaamgestelde gesin se problematiek kan bied. Die gevaar van 'n eensydige en derhalwe onvoldoende behandeling kan deur hierdie breër perspektief verminder word.

\section{Doelwitte}

\section{Sessie 1 - Aanmelding:}

Om die gesin te ontmoet en aan 'n terapeutiese verhouding te begin bou. Die daarstel van 'n terapeutiese klimaat en die opbou van terapeutiese krediete.

\section{Sessie 2 - Probleemoplossingsmetode:}

(a) Om kernkwessies wat verwant aan die hersaamgestelde gesinsdinamika is en moontlik in dié gesin teenwoordig kan wees, te assesseer.

(b) Identifisering van die probleem wat die gesin vir terapie gebring het. Die probleemoplossingsvaardighede moet geassesseer word en die gesin moet deur middel van ${ }^{1}$ psigoopvoeding probleemoplossingsvaardighede aanleer.

\section{Sessie 3 - Interaksionele metode:}

Die assessering van die egpaar se kommunikasiepatrone en -vaardighede en die aanleer van meer effektiewe kommunikasie.

\section{Sessie 4 - Strukturele metode:}

Om die egpaar deur middel van psigo-opvoeding insig in hul gesinstruktuur te laat ontwikkel en om die egpaarsubsisteem te herstruktureer.

\footnotetext{
${ }^{1}$ Psigo-opvoeding behels die verskaffing van inligting, ondersteuning, struktuur en gevoel van beheer wat gesinne (of gesinslede) in 'n krisis benodig. Die gesin word deur middel van psigo-opvoeding bemagtig en gemobiliseer, sodat insig in en begrip van die betrokke situasie verkry kan word. Die terapeut werk saam met die gesin om verandering
} 


\section{Sessie 5 - Kognitiewe metode:}

Om kognitiewe distorsies eie aan die hersaamgestelde gesin te identifiseer en te bespreek. Om verder ook insig in te win oor afbrekende kognitiewe distorsies en om meer toepaslike oortuigingsisteme te ontwikkel.

\section{Sessie 6 - Multigeneratiewe metode:}

Om die bestaan van die gesin van oorsprong se geloofsisteme te identifiseer en insig daarin te ontwikkel. Dit behels die ouers se gesin van oorsprong (toe hulle kinders was en ook hul eerste gesinne) en die kinders se aanvanklike kerngesinne. Om verder meer gedifferensieerd van die gesin van oorsprong te raak.

\section{Sessie 7 - Objekrelasie metode:}

Om individuele behoeftes en dieperliggende kwessies wat na die oppervlak gebring is, te assesseer en aan te spreek.

\section{Assessering}

Die egpaar (as egpaarsubsisteem) ervaar probleme om mekaar te akkommodeer en derhalwe tot 'n kompromie te kom, grootliks as gevolg van kognitiewe distorsies wat elk getrou aanhang. Hierdie uiteenlopende geloofsisteme kom van hul onderskeie gesinne van oorsprong wat radikaal van mekaar verskil en probleme in die huidige hersaamgestelde gesin veroorsaak. Ter verduideliking kan daar genoem word dat mnr L onderworpe was aan 'n streng en formele opvoedingstyl en dieselfde styl op sy kinders wil toepas, terwyl mev L aan 'n meer buigsame en informele opvoedingstyl gewoond is en haar kinders dus ook op daardie manier wil grootmaak. Die skrywers besluit dat die fokus nie primêr op verandering moet val nie (die een is nie noodwendig reg en die ander verkeerd nie), maar eerder op die ontwikkeling van begrip vir en insig in beide se persoonlike belewenisse en gevolglike optrede (wat waarskynlik sal lei tot verandering in ander fasette van hul huwelik- en gesinslewe).

\section{BEVINDINGS}

Die bevindings kom uit die volgende data:

- Literatuurstudie: Die vernaamste bevindings uit die literatuurstudie word by die bespreking van die hipoteses ingesluit.

- Gevallestudie: Die resultate van die gevallestudie word eweneens by die bespreking van die hipoteses ingesluit.

\section{Hipotese 1}

Indien die hersaamgestelde gesin oor onvoldoende voorbereiding vir die totstandkoming van hierdie gesin beskik, sal die hersaamgestelde gesin nie oor voldoende probleemoplossingsvaardighede beskik nie. Derhalwe is die blote aanleer van hierdie vaardighede nie genoeg om die potensiële multi-problematiek aan te spreek nie.

Hierdie hipotese word aanvaar. Probleemoplossing is ' $n$ beginpunt vir terapie en is tydens die eerste vlak van behandeling toegepas. Probleemoplossing is egter nie voldoende om die problematiek van 'n wanfunksionele gesin ten volle aan te spreek nie, soos wat Olsen ook bevind het (Olsen, 1993:57). Probleemoplossing is dus heel waarskynlik nie toereikend om die multiproblematiek van die hersaamgestelde gesin op te los nie. $\mathrm{Na}$ afloop van die sessie waartydens die probleemoplossingsmetode gebruik is, het die skrywers bevind dat die egpaar 
nie oor voldoende probleemoplossingsvaardighede beskik nie. Die egpaar het geargumenteer en beide het hardkoppig by hul standpunt gestaan. Wanneer hulle agtergekom het dat nie een van hulle die ander kon oortuig nie, het albei huweliksmaats die argument onopgelos gelaat. Die aanleer van probleemoplossingsvaardighede is wel op 'n elementêre vlak waardevol, maar hierdie egpaar se problematiek is té kompleks en té diep gewortel om eensydig deur die probleemoplossingsmetode aangespreek te word.

\section{Hipotese 2}

Indien afbrekende en negatiewe kommunikasiepatrone geïdentifiseer word, kan meer effektiewe kommunikasievaardighede met behulp van psigo-opvoeding en inoefening aangeleer en derhalwe toegepas word.

Hierdie hipotese word verwerp. Die egpaar het wel hul negatiewe kommunikasiepatrone geïdentifiseer, soos hul simmetriese patroon van beide hardkoppig by hul standpunt te staan. Maar die skrywers het bevind dat dieselfde probleem as by die probleemoplossingsmetode ook op die interaksionele metode van toepassing is. Die egpaar se kommunikasieproblematiek is reeds so diep gewortel (en vermeng met ander dieperliggende problematiek) dat die blote aanleer van meer effektiewe kommunikasievaardighede onvoldoende is om hul problematiek aan te spreek.

\section{Hipotese 3}

Indien insig in hul unieke struktuur as hersaamgestelde gesin verkry kan word en herstrukturering gevolglik kan plaasvind, sal die hersaamgestelde gesin volgens meer funksionele patrone kan funksioneer.

Hierdie hipotese word aanvaar. Die egpaar het wel insig in hul egpaarsubsisteem en in die tekort aan wedersydse tegemoetkoming en onderhandeling verkry. Die egpaar het besef dat tegemoetkoming slegs gedeeltelik in hulle verhouding plaasvind en dat hulle oor geen onderhandelingsvaardighede beskik nie. Herstrukturering en versterking van die egpaarsubsisteem het plaasgevind, wat tot die beginpunt van meer funksionele patrone in die hersaamgestelde gesin gelei het. Hierdie herstrukturering het plaasgevind deur eksplorering van die egpaar se subsisteem en deur op 'n huidige probleemarea te fokus. Deur middel van psigo-opvoeding het die egpaar insig ontwikkel en saam konstruktiewe besluite geneem ter verbetering van hul huidige situasie.

\section{Hipotese 4}

Indien dieper begrip van mekaar se oortuigingsisteme (kognitiewe distorsies) bereik kan word, sal die hersaamgestelde gesin meer toepaslike geloofsisteme kan konstrueer.

Hierdie hipotese word aanvaar. Die egpaar het begrip begin ontwikkel vir mekaar se teenstrydige geloofsisteme wat die aanvanklike konflik veroorsaak het. Só het die egpaar tot die besef gekom dat hulle teenstrydige geloofsisteme het. Hulle het besef dat konflik veroorsaak word omdat elkeen voel dat sy of haar siening die regte een is. Daar is verder gepoog om meer toepaslike geloofsisteme vanuit hul uiteenlopende perspektiewe te ontwikkel.

\section{Hipotese 5}

Indien begrip vir die invloed van die gesin van oorsprong tot stand kan kom, sal dit aanleiding gee tot insig in mekaar se oortuigingsisteme en tot 'n hoër vlak van selfdifferensiasie lei.

Hierdie hipotese word aanvaar. Die invloed van die gesin van oorsprong is erken en insig in 
besef presies in watter mate hul eie opvoeding as kinders verskil het en in watter mate hierdie verskillende ervaringe in hul opvoedingstyl met hul kinders deurskemer. Dit het veroorsaak dat die egpaar die belangrikheid van selfdifferensiasie van die gesin van oorsprong besef het.

Volgens die model word die laaste sessie (objekrelasiemetode) gebruik vir 'n gesinslid of huweliksmaat wat individuele berading nodig het na aanleiding van aspekte wat in die vorige sessies na vore gekom het. Die skrywers het dit egter nie nodig gevind om een van die huweliksmaats alleen vir berading te kontak nie.

Al die metodes van die model is toegepas. Dit was noodsaaklik dat die egpaar hulself moes bemagtig deur kennis op 'n interpersoonlike en intrapersoonlike vlak te bekom (veral wat hersaamgestelde gesinslewe betref), sodat die egpaar die vermoë kan ontwikkel om gelukkig as 'n hersaamgestelde gesin saam te woon. Die verantwoordelikheid berus nou by die egpaar self om die begrip wat hulle ontwikkel het en dit wat tydens die sessies geleer is, op 'n emosionele en kognitiewe vlak toe te pas.

Die skrywers het dit raadsaam gevind om eerstens op die problematiek van die huwelikspaar as ' $n$ eenheid in die hersaamgestelde gesin te fokus. Die fokus sal vervolgens na die kinders en spesifiek na hulle moontlike problematiek in die hersaamgestelde gesin verskuif. Weens 'n gebrek aan ruimte in hierdie studie is die kinders egter nie breedvoerig as fokuspunt behandel nie. Die model is egter met die huwelikspaar (en hul problematiek in 'n hersaamgestelde gesin) deurloop en in die lig van voldoende terugvoer, kan daar aanvaar word dat dit wel suksesvol toegepas is.

\section{TEKORTKOMINGE EN AANBEVELINGS}

\section{- Die model kon met groter buigsaamheid toegepas gewees het}

Ter toetsing van die struktuur is die model vir navorsingsdoeleindes streng nagevolg, maar in die praktyk sal dit gevaar inhou as 'n terapeut die gesin bloot stapsgewys deur die model stuur. Hierdie model en die verskeie metodes waaruit dit saamgestel is, is uiters bruikbaar en dit kan definitief met groot sukses in terapie met hersaamgestelde gesinne gebruik word, maar die terapeut sal buigsaam moet wees wat die toepassing van die metodes in die unieke gesin betref.

Die beginpunt van terapie kan steeds die probleemoplossingsmetode bly waartydens die terapeut die gesin se problematiek en probleemoplossingsvaardighede assesseer. Daarna kan die terapeut vrylik van die metodes gebruik maak na gelang van die gesin se unieke situasie. So kan die terapeut byvoorbeeld die probleemoplossingsmetode gebruik om die kernproblematiek te identifiseer en daarna, deur gebruik te maak van die multigeneratiewe metode, die gesin se problematiek aanspreek. Daar kan weer teruggekeer word na onderskeidelik die probleemoplossings- en interaksionele metode en die terapeut kan deur van psigo-opvoeding gebruik te maak, vir die gesin effektiewe probleemoplossings- en kommunikasievaardighede leer.

Ten opsigte van 'n meer buigsame toepassing van die model, hou die skrywers die volgende diagram aan die leser voor as 'n aangepaste geïntegreerde gesinsterapeutiese model: 


\section{DIAGRAM 2 \\ AANGEPASTE GEÏNTEGREERDE GESINSTERAPEUTIESE MODEL}

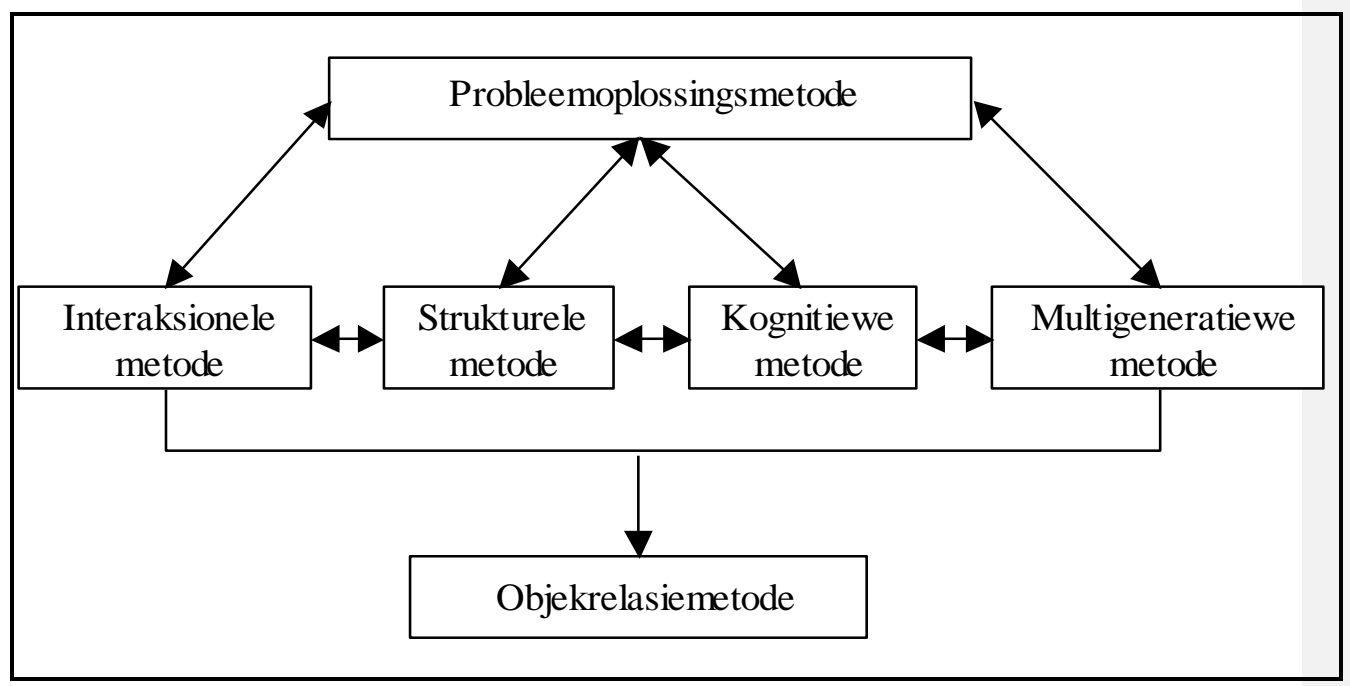

\section{- Die aanleer van probleemoplossings- en kommunikasievaardighede kon eers na afloop van die behandeling van die emosionele kwessies plaasgevind het}

Die skrywers is van mening dat die egpaar dit meer waardevol sou gevind het as hulle die probleemoplossings- en kommunikasievaardighede eers later geleer het, met ander woorde nadat die emotiewe kwessies wat die struikelblokke veroorsaak het, in perspektief geplaas is en katarsis plaasgevind het. In dié geval sou die probleemdefiniëring doeltreffender kon wees en sou assessering van kommunikasiepatrone ook beter kon plaasvind.

\section{- Meer as een sessie kon per metode toegelaat gewees het}

Die skrywers het byvoorbeeld een sessie vir die probleemoplossingsmetode en een vir die interaksionele metode gebruik, en so meer. Ruimte moet gelaat word vir meer tyd vir spesifike metodes, aangesien een metode moontlik op 'n beter manier die kernproblematiek van die hersaamgestelde gesin kan aanspreek as 'n ander metode. (Die model was nie voorskriftelik ten opsigte van een sessie per metode nie, maar die skrywers het na hul ervaring met die model besef dat meer as een sessie per metode wel waardevol kan wees.)

\section{- Die uitsluiting van die strategiese metode}

Die strategiese metode is ' $\mathrm{n}$ gesinsterapeutiese metode wat nie as deel van hierdie studie ingesluit is nie. Die skrywers het tydens hul bestudering van die literatuur van hierdie metode bewus word en is van mening dat dit ' $n$ waardevolle bydrae tot die geïntegreerde gesinsterapeutiese model kan lewer. Die strategiese metode fokus volgens Carlson et al. (1997:62) onder meer op die sosiale konteks en op die lewensiklusproblematiek, wat albei belangrike kwessies ten opsigte van die hersaamgestelde gesin is. Die insluiting van die strategiese metode en die buigsame gebruik daarvan na aanleiding van die terapeut en die gesin 


\section{SLOTOPMERKING}

Die doel van hierdie artikel was om 'n geïntegreerde benadering tot gesinsterapie voor te stel en om kennis en begrip oor die problematiek van die hersaamgestelde gesin te vermeerder. Die hoop word gekoester dat daar na afloop van die lees van hierdie artikel by die leser groter begrip, insig en empatie vir lede van hersaamgestelde gesinne sal bestaan en dat die waarde van 'n geïntegreerde gesinsterapeutiese werkwyse besef sal word.

\section{BIBLIOGRAFIE}

BECVAR, D.S. \& BECVAR, R.J. 2000. Family therapy: A systemic integration. Boston: Allyn \& Bacon.

BOOTH, A. \& DUNN, J. 1994. Stepfamilies: Who benefits? Who does not? Hillsdale: Erlbaum.

BRITZ-SCHEEPERS, L.B. \& DU PREEZ, M.S.E. 1994. Die hersaamgestelde gesin: 'n maatskaplike perspektief. Social Work/Maatskaplike Werk, 30(3):237-247.

CARLSON, J.; SPERRY, L. \& LEWIS, J.A. 1997. Family therapy: Ensuring treatment efficacy. California: Brooks/Cole.

CARTER, B. \& McGOLDRICK, M. 1999. The expanded family life circle: Individual family and social perspectives. Boston: Allyn \& Bacon.

DU PLESSIS, J. 1994. Enkele kenmerke van en probleme eie aan die hersaamgestelde gesin. Lyra Academica, 9(2):65-68.

GOLDENBERG, I. \& GOLDENBERG, G.H. 2000. Family therapy: An overview. California: Brooks/Cole.

JUDD, C.M.; SMITH, E.R. \& KIDDER, L.H. 1991. Research methods in social relations. New York: Harcourt Brale Jovanovich College Publishers.

KELLEY, P. 1995. Developing healthy stepfamilies: 20 families tell their stories. New York: Haworth Press.

LEBOW, J.L. 1987. Developing a personal integration in family therapy: Principles for model construction and practice. Journal of Marital and Family Therapy, 13(1):1-14.

MINUCHIN, S. 1996. Families and family therapy. New York: Routledge.

OLSEN, D.C. 1993. Integrative family therapy. USA: Augsberg Fortress.

PARKINSON, L. 1987. Separation, divorce and families. London: Macmillan.

PRINSLOO, E. 1993. Topical problems of the reconstituted family in contemporary society. Educare, 22(1/2):38-48.

Sentrale Statistiekdiens van Suid Afrika. 1998. Statistiese berig P0307: Huwelike en egskeidings. Pretoria: Staatsdrukker.

VAN DER WESTHUIZEN, C.H.J. 1997. Gesinsterapie. Pretoria: U.P. Drukkers.

VISHER, E.B. \& VISHER, J.S. 1988. Old loyalties, new ties. New York: Brunner/Mazel.

VISHER, E.B. \& VISHER, J.S. 1996. Therapy with stepfamilies. New York: Brunner/Mazel. 